\title{
Patrinia scabiosaefolia extract suppresses proliferation and promotes apoptosis by inhibiting the STAT3 pathway in human multiple myeloma cells
}

\author{
JUN PENG ${ }^{1 *}$, YOUQIN CHEN ${ }^{3 *}$, JIUMAO LIN $^{1}$, QUNCHUAN ZHUANG $^{1}$, \\ WEI XU ${ }^{2}, Z^{2} H E N F E N G ~ H_{N}{ }^{1}$ and THOMAS J. SFERRA ${ }^{3,4}$ \\ ${ }^{1}$ Academy of Integrative Medicine; ${ }^{2}$ Department of Pharmacology, Fujian University of Traditional Chinese Medicine, \\ Fujian 350108, P.R. China; Departments of ${ }^{3}$ Pediatrics and ${ }^{4}$ Biochemistry and Molecular Biology, \\ The University of Oklahoma Health Sciences Center, Oklahoma, OK 73190, USA
}

Received September 28, 2010; Accepted December 27, 2010

DOI: $10.3892 / \mathrm{mmr} .2011 .413$

\begin{abstract}
Signal transducer and activator of transcription 3 (STAT3) plays an important role in tumor cell survival and proliferation and thus has become a major focus in the development of anti-cancer therapies. Patrinia scabiosaefolia has been used for the treatment of various types of cancer. However, the precise mechanism of the anti-cancer activity of Patrinia scabiosaefolia remains unclear. In this study, we evaluated the effect of the ethanol extract of Patrinia scabiosaefolia (EEPS) on proliferation and apoptosis in human multiple myeloma U266 cells that persistently express phosphorylated STAT3, and investigated the possible molecular mechanisms mediating its biological effects. We found that EEPS inhibited the phosphorylation of STAT3 in U266 cells. Consequently, the inhibitory effect of EEPS on STAT3 activation resulted in the suppression of cell proliferation and the induction of cell apoptosis. Moreover, EEPS treatment inhibited the expression of cyclin D1 (a promoter of cell proliferation) and
\end{abstract}

Correspondence to: Professor Zhenfeng Hong, Academy of Integrative Medicine, Fujian University of Traditional Chinese Medicine, 1 Huatuo Road, Minhou Shangjie, Fuzhou, Fujian 350108, P.R. China

E-mail: zfhong1953@163.com

Dr Thomas J. Sferra, Department of Pediatrics and Biochemistry and Molecular Biology, The University of Oklahoma Health Sciences Center, 940 Stanton L. Young Boulevard, Oklahoma, OK 73190, USA E-mail: thomas-sferra@ouhsc.edu

${ }^{*}$ Contributed equally

Abbreviations: STAT3, signal transducer and activator of transcription 3; EEPS, ethanol extract of Patrinia scabiosaefolia; DMSO, dimethyl sulfoxide; MTT, 3-(4,5-dimethyl-thiazol-2-yl)-2,5diphenyltetrazolium bromide

Key words: anti-tumor, U266 cells, phytotherapy, signal transducer and activator of transcription 3 pathway, Patrinia scabiosaefolia
Bcl-2 (an inhibitor of apoptosis), two important target genes of the STAT3 signaling pathway. Our findings for the first time demonstrate that Patrinia scabiosaefolia inhibits proliferation and promotes the apoptosis of cancer cells via inhibition of the STAT3 pathway, which may in part explain its anti-cancer activity.

\section{Introduction}

Signal transducer and activator of transcription 3 (STAT3), a transcription factor that plays an important role in cell survival and proliferation, is strongly associated with tumorigenesis (1-9). Constitutive activation of STAT3 is found in several types of human cancer and commonly indicates poor prognosis (10-14). STAT3 is activated by many growth factors and cytokines, including epidermal growth factor (15) and interleukin-6 (16). STAT3 activation is mediated by phosphorylation at tyrosine 705 by receptor and non-receptor protein tyrosine kinases, such as epidermal growth factor receptor kinase (17) and Janus-activated kinases $(18,19)$. The phosphorylation of STAT3 in the cytoplasm induces its homodimerization, nuclear translocation and DNA binding, resulting in the expression of genes mediating proliferation (e.g., cyclin D1) and preventing apoptosis (e.g., Bcl-2) (20-23). Therefore, suppression of STAT3 activation has been a major focus in the development of novel anti-cancer therapies.

Natural products have been considered alternative medicine for many years. Numerous plants and their constituents have been shown to possess beneficial therapeutic effects for various diseases, including cancer $(24,25)$. Patrinia scabiosaefolia, a perennial plant natively distributed in eastern Asia, is a well-known oriental folk-medicine believed to have 'heat-clearing and detoxifying' properties. It has long been used in China for the treatment of several ailments, including edema, appendicitis, endometritis and other inflammatory illnesses (26). Patrinia scabiosaefolia is also used as an important component in formulated prescriptions of Chinese traditional medicine to treat gastrointestinal cancer (27). However, the precise mechanism of its tumoricidal activity remains unclear. 
In this study, we evaluated the effect of the ethanol extract of Patrinia scabiosaefolia (EEPS) on the proliferation and apoptosis of human multiple myeloma U266 cells, and investigated the possible molecular mechanisms mediating its biological effect. We found that EEPS inhibited the proliferation and induced the apoptosis of the U266 cells. More importantly, EEPS suppressed the constitutive phosphorylation of STAT3, accompanied by the down-regulation of cyclin D1 and Bcl-2. Our findings for the first time demonstrate that Patrinia scabiosaefolia inhibits the proliferation and promotes the apoptosis of cancer cells via the inhibition of the STAT3 pathway, which is likely one of the mechanisms underlying its anti-cancer activity.

\section{Materials and methods}

Materials and reagents. RPMI-1640, fetal bovine serum (FBS), penicillin-streptomycin, Trypsin-EDTA, TRIzol reagent, the iBlot Western Detection Stack/iBlot Dry Blotting System and the caspase-3 colorimetric protease assay kit were purchased from Invitrogen (Carlsbad, CA, USA). Bcl-2, cyclin D1 and phospho-STAT3 $\left(\mathrm{Tyr}^{705}\right.$ ) antibodies as well as horseradish peroxidase-conjugated secondary antibodies were obtained from Cell Signaling (Beverly, MA, USA). An Annexin V apoptosis detection kit was obtained from Becton Dickinson (San Jose, CA, USA). All other chemicals, unless otherwise stated, were obtained from Sigma Chemical (St. Louis, MO, USA).

Preparation of ethanol extract from Patrinia scabiosaefolia. Five hundred grams of Patrinia scabiosaefolia were extracted with $5,000 \mathrm{ml}$ of $85 \%$ ethanol using a refluxing method and filtered. The ethanol solvent was evaporated on a rotary evaporator (Model RE-2000; Shanghai Yarong, China) and concentrated to a relative density of 1.05. A dried powder EEPS was obtained by spray desiccation using a spray dryer (Model B-290; Buchi, Switzerland). The EEPS was dissolved in DMSO to a stock concentration of $200 \mathrm{mg} / \mathrm{ml}$ and stored at $-20^{\circ} \mathrm{C}$. The working concentrations of EEPS were made by diluting the stock solution in the culture medium. The final concentration of DMSO in the medium for all experiments was $<0.5 \%$.

Cell culture. Human multiple myeloma U266 cells were obtained from American Type Culture Collection (ATCC; Manassas, VA, USA). The cells were grown in RPMI-1640 containing $10 \%$ (v/v) FBS, $100 \mathrm{U} / \mathrm{ml}$ penicillin and $100 \mu \mathrm{g} / \mathrm{ml}$ streptomycin in a $37^{\circ} \mathrm{C}$ humidified incubator with $5 \% \mathrm{CO}_{2}$.

Western blot analysis. U266 cells $\left(2 \times 10^{5}\right)$ were seeded into 6-well plates in $2 \mathrm{ml}$ medium and treated with various concentrations of EEPS for $24 \mathrm{~h}$. The treated cells were lysed with mammalian cell lysis buffer (M-PER; Thermo Scientific, Rockford, IL, USA) containing protease and phosphatase inhibitor cocktails (EMD Biosciences and Sigma Chemical, USA, respectively). The lysates were resolved in $12 \%$ SDS-PAGE gels and electroblotted. The PVDF membranes were blocked with 5\% skimmed milk and probed with primary antibodies against phospho-specific STAT3 $\left(\mathrm{Tyr}^{705}\right)$, Bcl-2 and cyclin D1 $(1: 1,000)$ overnight at $4^{\circ} \mathrm{C}$. Blots were washed, exposed to secondary antibody for $2 \mathrm{~h}$ and developed using Super Signal Pico Substrate (Thermo Scientific). Images were captured using a Kodak Image Station 400R (Kodak, Rochester, NY, USA).

Evaluation of cell viability by MTT assay. Cell viability was assessed by the 3-(4,5-dimethylthiazol-2-yl)-2,5-diphenyltetrazolium bromide (MTT) colorimetric assay. U266 cells were seeded into 96-well plates at a density of $1 \times 10^{4}$ cells/ well in $0.1 \mathrm{ml}$ medium. The cells were treated with various concentrations of EEPS for $24 \mathrm{~h}$ or with $0.75 \mathrm{mg} / \mathrm{ml}$ of EEPS for different time periods. Treatment with $0.5 \%$ DMSO was included as the vehicle control. At the end of the treatment, $10 \mu \mathrm{l}$ MTT ( $5 \mathrm{mg} / \mathrm{ml}$ in phosphate buffered saline) were added to each well and the samples were incubated for an additional $4 \mathrm{~h}$ at $37^{\circ} \mathrm{C}$. The purple-blue MTT formazan precipitate was dissolved in $100 \mu \mathrm{l}$ DMSO. The absorbance was measured at $570 \mathrm{~nm}$ using an ELISA plate reader (Model EXL800; BioTek, USA).

Colony formation. The U266 cells were seeded into 24-well plates at a density of $0.5 \times 10^{4}$ cells/well and treated with various concentrations of EEPS for $24 \mathrm{~h}$. The cells were then diluted in fresh medium in the absence of EEPS and reseeded into 6-well plates at a density of $1.0 \times 10^{3}$ cells/well. After incubation for 7 or 8 days in a $37^{\circ} \mathrm{C}$ humidified incubator with $5 \% \mathrm{CO}_{2}$, formed colonies were fixed with $10 \%$ formaldehyde, stained with $0.01 \%$ crystal violet and counted. Cell survival was calculated by normalizing the survival of the control cells as $100 \%$.

Detection of apoptosis by flow cytometry analysis with Annexin V/PI staining. After incubation with various concentrations of EEPS, the apoptosis of the U266 cells was determined by flow cytometry analysis using a fluorescenceactivated cell sorting (FACS) caliber (Becton Dickinson) and an Annexin V-fluorescein isothiocyanate (FITC)/propidium iodide (PI) kit. Staining was performed according to the manufacturer's instructions. The percentage of cells in early apoptosis was calculated by Annexin V-positivity and PI-negativity, while the percentage of cells in late apoptosis was calculated by Annexin $\mathrm{V}$-positivity and PI-positivity.

Analysis of caspase activation. The activity of caspase-3 was determined by a colorimetric assay kit following the manufacturer's instructions. Briefly, after treatment with various concentrations of EEPS for $24 \mathrm{~h}$, U266 cells were lysed with the manufacturer's provided lysis buffer for $30 \mathrm{~min}$ on ice. The lysed cells were centrifuged at $16,000 \mathrm{x} g$ for $10 \mathrm{~min}$. The protein concentration of the clarified supernate was determined and $100 \mu \mathrm{g}$ of the protein were incubated with $50 \mu \mathrm{l}$ of the colorimetric tetrapeptide, Asp-Glu-Val-Asp (DEVD)-pnitroaniline (pNA), at $37^{\circ} \mathrm{C}$ in the dark for $2 \mathrm{~h}$. Samples were read at $405 \mathrm{~nm}$ in an ELISA plate reader. Data were normalized to the caspase-3 activity in control cells (treated with $0.5 \%$ DMSO vehicle) and represented as 'fold of control'.

RNA extraction and RT-PCR analysis. U266 cells $\left(2 \times 10^{5}\right)$ were seeded into 6-well plates in $2 \mathrm{ml}$ medium and treated with various concentrations of EEPS for $24 \mathrm{~h}$. Total RNA from 


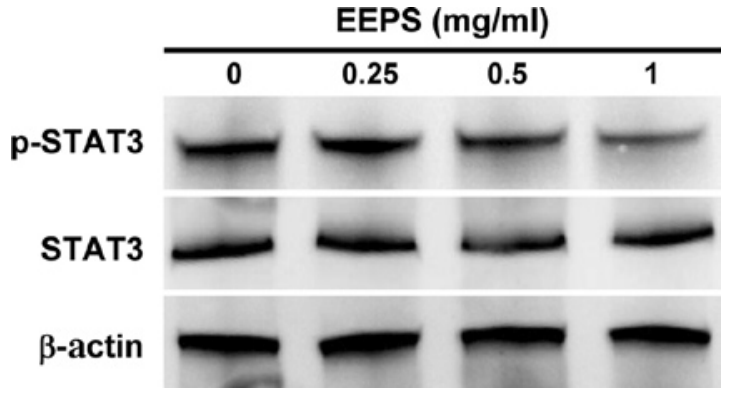

Figure 1. Effect of EEPS on the phosphorylation of STAT3 in U266 cells. U266 cells were treated with the indicated concentrations of EEPS for $24 \mathrm{~h}$ and STAT3 phosphorylation was determined by Western blotting using an antibody that recognizes phosphorylated STAT3 at $\mathrm{Tyr}^{705}$. $\beta$-actin was used as the internal control. Data are representative of three independent experiments.

the U266 cells was isolated with TRIzol Reagent. Oligo(dT)primed RNA $(1 \mu \mathrm{g})$ was reverse-transcribed with SuperScript II reverse transcriptase (Promega Corporation, Madison, WI, USA) according to the manufacturer's instructions. The obtained cDNA was used to determine the amount of $\mathrm{Bcl}-2$ or Bax mRNA by PCR. GAPDH was used as an internal control. The DNA bands were examined using a Gel Documentation System (Model Gel Doc 2000; Bio-Rad, USA).

Statistical analysis. All data are the means of three determinations, and were analyzed using the SPSS package for Windows (Version 11.5). Statistical analysis of the data was performed with the Student's t-test and ANOVA. Differences with $\mathrm{P}<0.05$ were considered statistically significant.

\section{Results}

EEPS inhibits the activation of STAT3. To investigate the effect of EEPS on the phosphoralytion of STAT3 in cancer cells, we used human multiple myeloma U266 cells that express persistently phosphorylated STAT3 (i.e., constitutively activated STAT3) and performed Western blot analysis using antibody that recognizes STAT3 phosphorylation at $\mathrm{Tyr}^{705}$. As shown in Fig. 1, EEPS inhibited the constitutive activation of STAT3 in U266 cells in a dose-dependent manner. The levels of non-phosphorylated STAT3 remained unchanged after EEPS treatment.

EEPS inhibits the proliferation of U266 cells. STAT3 activation plays an important role in cell proliferation and survival. Therefore, we examined the inhibitory effect of EEPS on U266 cell growth. The MTT assay was used to compare the relative number of cells in EEPS treated monolayers to untreated controls. The data presented in Fig. 2A showed that treatment with $0.25-1 \mathrm{mg} / \mathrm{ml}$ of EEPS for $24 \mathrm{~h}$ dosedependently reduced cell viability by $15-66 \%$ compared to untreated control cells $(\mathrm{P}<0.01)$, with an estimated half maximal inhibitory concentration $\left(\mathrm{IC}_{50}\right)$ value of $0.75 \mathrm{mg} /$ $\mathrm{ml}$. The cell viability was decreased to $34 \%$ at the highest concentration of EEPS $(1 \mathrm{mg} / \mathrm{ml})$ used in this study. We also evaluated the effect of $0.75 \mathrm{mg} / \mathrm{ml}$ of EEPS ( $\mathrm{IC}_{50}$ value) on cell viability with incubation for different periods of time. As shown in Fig. 2B, treatment with $0.75 \mathrm{mg} / \mathrm{ml}$ of EEPS led to a
$\mathbf{A}$

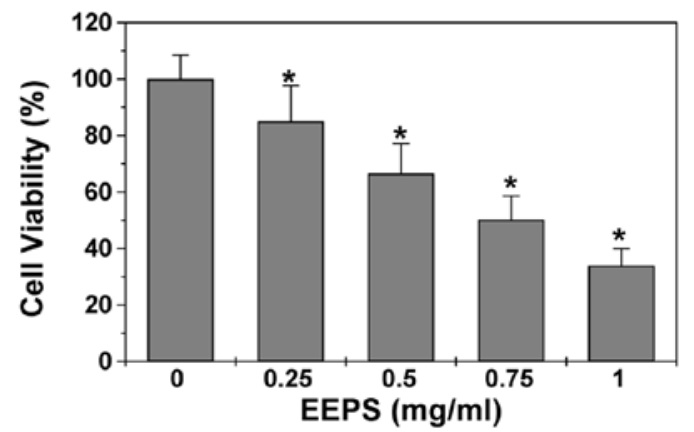

B

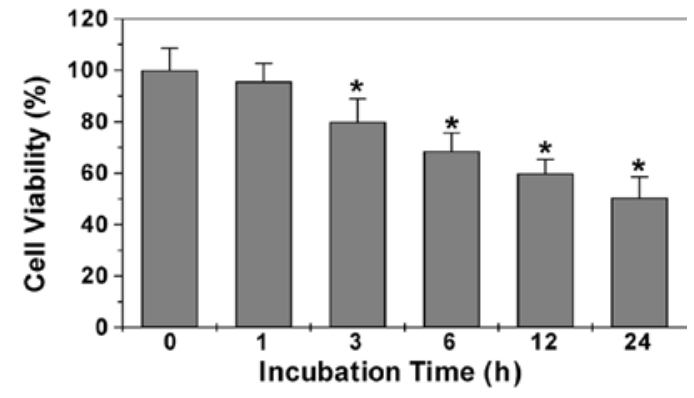

C

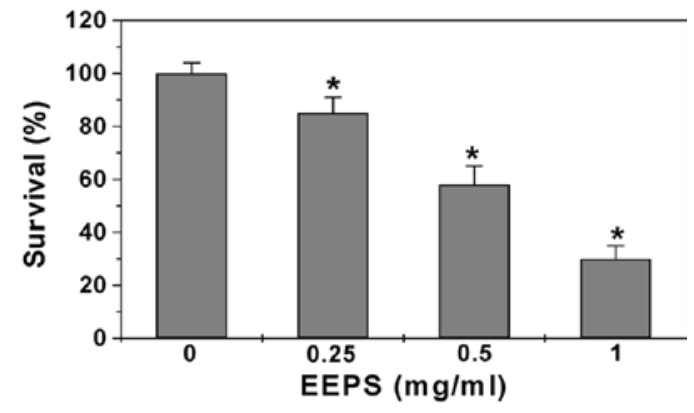

Figure 2. Effect of EEPS on the proliferation of U266 cells. Cell viability was determined by the MTT assay after U266 cells were treated with the indicated concentrations of EEPS for $24 \mathrm{~h}$ (A) or with $0.75 \mathrm{mg} / \mathrm{ml}$ of EEPS for the indicated time periods (B). Cell survival was evaluated by colony formation assay (C). The data were normalized to the viability or survival of control cells (100\%, treated with $0.5 \%$ DMSO vehicle). Data are averages with SD (error bars) from at least three independent experiments. ${ }^{*} \mathrm{P}<0.01$ vs. control cells.

gradual decrease in cell viability with an increase in exposure time. To further verify these results, we examined the effect of EEPS on U266 cell survival using a colony formation assay. As shown in Fig. 3, treatment with $0.25,0.5$ and $1 \mathrm{mg} / \mathrm{ml}$ of EEPS for $24 \mathrm{~h}$ dose-dependently reduced the cell survival rate by 15,42 and $70 \%$ compared to untreated control cells $(\mathrm{P}<0.01)$. Taken together, these data demonstrate that EEPS inhibits the proliferation of U266 cells.

EEPS induces apoptosis of U266 cells. The effect of EEPS on U266 cell apoptosis was determined using Annexin-V/PI staining followed by FACS analysis. In this assay, the Annexin V/PI double-negative population (labeled as LL in the FACS diagram) represents viable cells, and the Annexin V-positive/PI-negative and Annexin V-positive/PI-positive populations (labeled as LR or UR in the FACS diagram) represent cells undergoing early and late apoptosis, respectively. As shown in Fig. 3A and B, the percentage of cells undergoing apoptosis following treatment with $0,0.25,0.5$ and $1 \mathrm{mg} / \mathrm{ml}$ of EEPS (including early and late apoptotic cells) was $10.2 \pm 0.68,13.3 \pm 0.99,19.0 \pm 1.87$ and 
A
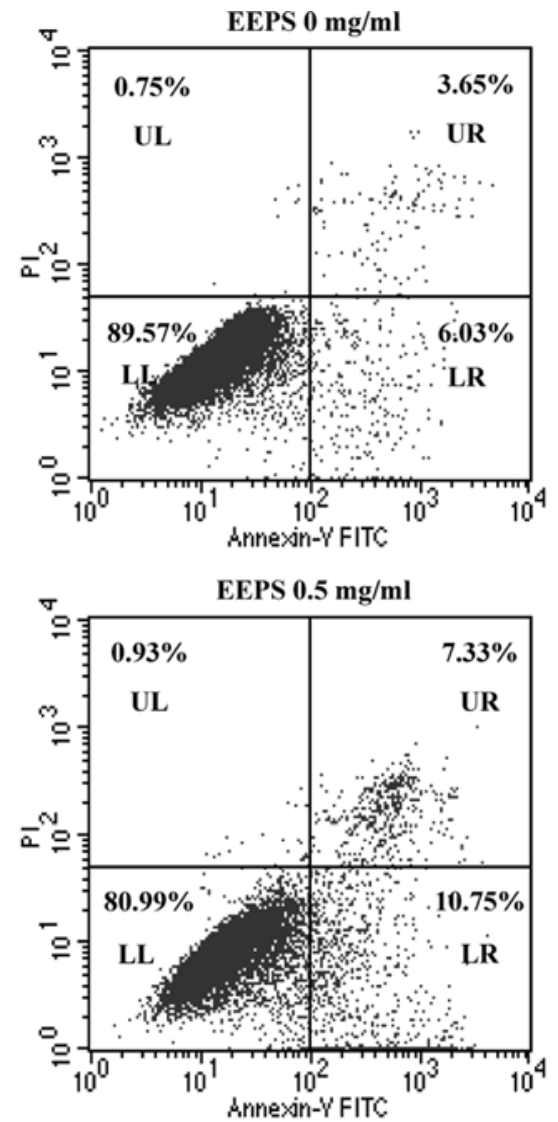

B

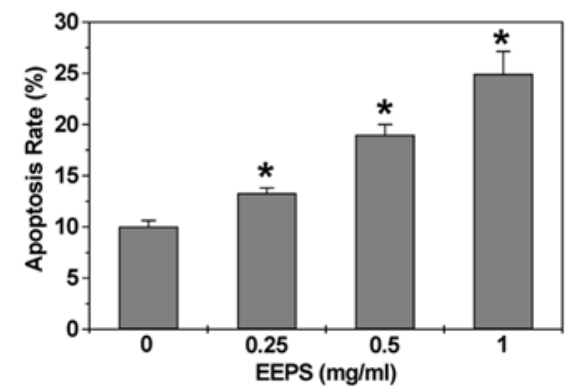

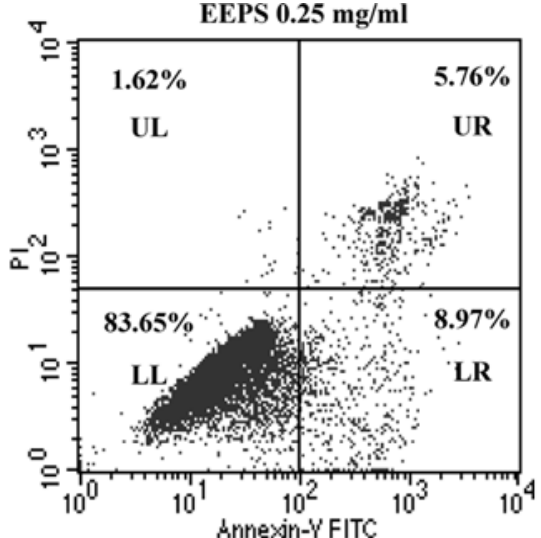

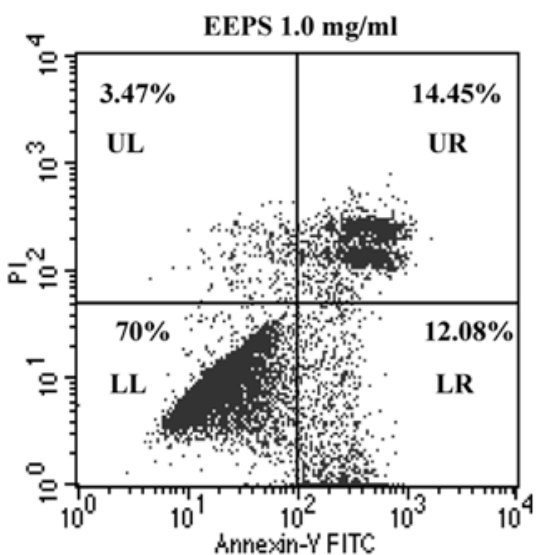

C

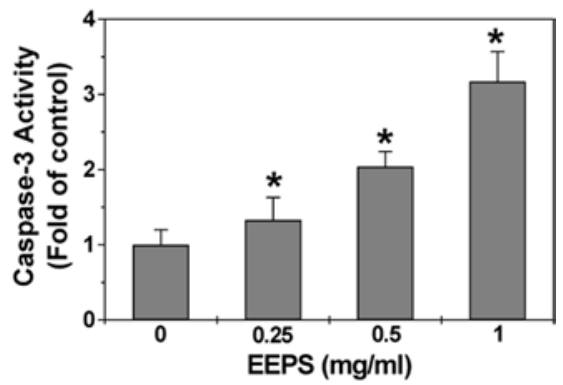

Figure 3. Effect of EEPS on the apoptosis of U266 cells. (A) U266 cells were treated with the indicated concentrations of EEPS for 24 h, stained with Annexin V/PI and analyzed by FACS. Representative FACS analysis scatter-grams of Annexin V/PI staining display four different cell populations labeled as: double-negative stained cells (LL, lower left) indicating a live cell population; Annexin V-positive/PI-negative stained cells (LR, lower right) and Annexin V/ PI double-positive stained cells (UR, upper right) representing early apoptosis and late apoptosis, respectively; Annexin V-negative and PI-positive stained cells (UL, upper left) showing dead cells. Data shown are representative of three independent experiments. (B) Quantification of FACS analysis. (C) Caspase-3 activity was determined by a colorimetric assay. The data were normalized to the caspase activities within control cells (treated with $0.5 \%$ DMSO vehicle) and represented as: 'fold of control'. Data are averages with SD (error bars) from at least three independent experiments. *P<0.01 vs. control cells.

$24.93 \pm 2.21 \%$, respectively ( $\mathrm{P}<0.01$, vs. untreated control cells). To identify the downstream effectors in the apoptotic signaling pathway, the activation of caspase- 3 was examined by a colorimetric assay using a specific chromophore, DEVD-pNA. As shown in Fig. 3C, EEPS treatment significantly and dosedependently induced the activation of caspase-3 in U266 cells $(\mathrm{P}<0.01$, vs. untreated control cells). These data together demonstrate that EEPS treatment induces U266 cell apoptosis in a dose-dependent manner.

EEPS down-regulates the expression of Bcl-2 and cyclin D1. Since STAT3 activation has been shown to regulate the expression of various gene products mediating cell prolif- eration and preventing apoptosis, we examined the effect of EEPS on the expression of the pro-proliferative cyclin D1 and the anti-apoptotic Bcl-2 by RT-PCR and Western blot analysis. The results of the RT-PCR assay showed that EEPS treatment profoundly reduced $\mathrm{Bcl}-2$ and cyclin D1 mRNA levels in U266 cells (Fig. 4A). Data from Western blot analysis showed that the pattern of protein expression of Bcl-2 and cyclin D1 was similar to their respective mRNA levels (Fig. 4B).

\section{Discussion}

The transcription factor STAT3 is an oncogenic protein that is constitutively activated in most tumor cells, but not in normal 


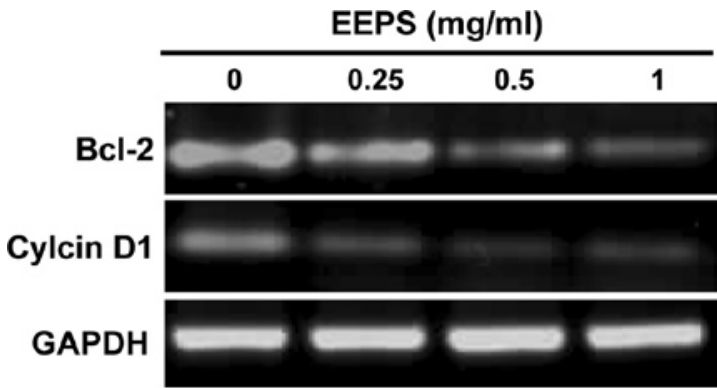

B

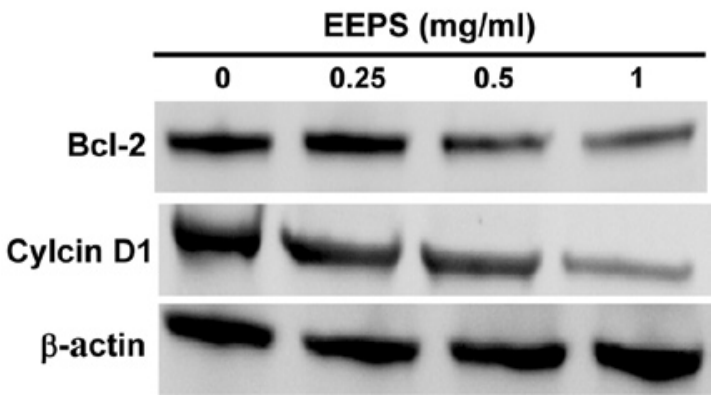

Figure 4. Effect of EEPS on the expression of Bcl-2 and cyclin D1 in U266 cells. Cells were treated with the indicated concentrations of EEPS for $24 \mathrm{~h}$. (A) The mRNA levels of Bcl-2 and cyclin D1 were determined by RT-PCR. (B) The protein expression levels of Bcl-2 and cyclin D1 were determined by Western blot analysis. GAPDH and $\beta$-actin were used as the internal controls for the RT-PCR or Western blotting, respectively. Data are representative of three independent experiments.

cells (1-14). Phosphorylation of STAT3 at tyrosine 705 leads to its homodimerization, nuclear translocation and DNA binding. This in turn regulates the expression of genes that promote cell proliferation or provide resistance to apoptosis. The unregulated increase in cell proliferation and reduction in cell apoptosis are both strongly associated with tumorigenesis (28). In addition, disrupted apoptosis contributes to the drug resistance of tumor cells, which has become a significant obstacle for the successful management of patients with malignant tumors (29). Moreover, many currently used anti-cancer agents contain potent intrinsic cytotoxicity to normal cells (30). Resistance to chemotherapy and cytotoxicity to normal cells limit the effectiveness of current cancer therapies, thus there is a need for the development of new therapeutic agents. Natural products have been the subject of recent interest as anti-cancer agents, as they have relatively few side effects and have been used as alternative remedies for a variety of diseases, including cancer (30,31). Patrinia scabiosaefolia, a traditional 'heat-clearing and detoxifying' Chinese herbal medicine, has many reported pharmacological applications, including use as an anti-cancer agent $(32,33)$. However, the mode of action of its anti-tumor effect is largely unknown. Before Patrinia scabiosaefolia can be further developed as an anti-cancer agent, its anti-tumor activity and underlying molecular mechanism should first be elucidated.

In the present study, we report that EEPS inhibits the phosphorylation of STAT3 in human multiple myeloma U266 cells in a dose-dependent fashion. The inhibitory effect of EEPS on STAT3 activation results in the suppression of proliferation and the induction of apoptosis in U266 cells. Consistent with the inhibition of STAT3 activation, we also found that EEPS treatment reduces the expression of cyclin D1 and Bcl-2 at both transcriptional and translational levels. Cyclin D1 and Bcl-2 are important target genes of the STAT3 pathway, and mediate cell proliferation or prevent cell apoptosis, respectively. Overexpression of cyclin D1 and Bcl-2 is associated with the pathogenesis of cancer.

In conclusion, our data for the first time demonstrate that EEPS inhibits proliferaion and induces apoptosis in cancer cells via the inhibition of the STAT3 pathway. These results suggest that Patrinia scabiosaefolia may be a potential novel therapeutic agent for the treatment of several different types of cancer with constitutive activation of STAT3.

\section{Acknowledgements}

This study was sponsored by the Open Fund of Fujian Key Laboratory of Integrative Medicine on Geriatrics (2008J1004), the Natural Science Foundation of Fujian Province (2010J01195), the National Natural Science Foundation of China (81073097) and the Developmental Fund of Chen Keji Integrative Medicine (CKJ 2010019).

\section{References}

1. Darnell JE Jr: Transcription factors as targets for cancer therapy. Nat Rev Cancer 2: 740-749, 2002.

2. Aggarwal BB, Kunnumakkara AB, Harikumar KB, Gupta SR, Tharakan ST, Koca C, Dey S and Sung B: Signal transducer and activator of transcription-3, inflammation, and cancer: how intimate is the relationship? Ann NY Acad Sci 1171: 59-76, 2009.

3. Buettner R, Mora LB and Jove R: Activated STAT signaling in human tumors provides novel molecular targets for therapeutic intervention. Clin Cancer Res 8: 945-954, 2002.

4. Bromberg J and Darnell JE Jr: The role of STATs in transcriptional control and their impact on cellular function. Oncogene 19: 2468-2473, 2000.

5. Bowman T, Garcia R, Turkson J and Jove R: STATs in oncogenesis. Oncogene 19: 2474-2488, 2000.

6. Bromberg JF, Wrzeszczynska MH, Devgan G, Zhao Y, Pestell RG, Albanese C and Darnell JE Jr: Stat3 as an oncogene. Cell 98: 295-303, 1999.

7. Turkson J and Jove R: STAT proteins: novel molecular targets for cancer drug discovery. Oncogene 19: 6613-6626, 2000.

8. Inghirami G, Chiarle R, Simmons WJ, Piva R, Schlessinger K and Levy DE: New and old functions of STAT3: a pivotal target for individualized treatment of cancer. Cell Cycle 4: 1131-1133, 2005.

9. Klampfer L: Signal transducers and activators of transcription (STATs): novel targets of chemopreventive and chemotherapeutic drugs. Curr Cancer Drug Targets 6: 107-121, 2006.

10. Alvarez JV, Greulich H, Sellers WR, Meyerson M and Frank DA: Signal transducer and activator of transcription 3 is required for the oncogenic effects of non-small-cell lung cancer-associated mutations of the epidermal growth factor receptor. Cancer Res 66: 3162-3168, 2006

11. Yin W, Cheepala S, Roberts JN, Syson-Chan K, Digiovanni J and Clifford JL: Active Stat3 is required for survival of human squamous cell carcinoma cells in serum-free conditions. Mol Cancer 5: 15, 2006.

12. Kusaba T, Nakayama T, Yamazumi K, Yakata Y, Yoshizaki A, Inoue K, Nagayasu T and Sekine I: Activation of STAT3 is a marker of poor prognosis in human colorectal cancer. Oncol Rep 15: 1445-1451, 2006.

13. Brantley EC and Benveniste EN: Signal transducer and activator of transcription-3: a molecular hub for signaling pathways in gliomas. Mol Cancer Res 6: 675-684, 2008.

14. Grivennikov S, Karin E, Terzic J, Mucida D, Yu GY, Vallabhapurapu S, Scheller J, Rose-John S, Cheroutre H, Eckmann L and Karin M: IL-6 and Stat 3 are required for survival of intestinal epithelial cells and development of colitisassociated cancer. Cancer Cell 15: 103-13, 2009.

15. Zhong Z, Wen Z and Darnell J: Stat3: a STAT family member activated by tyrosine phosphorylation in response to epidermal growth factor and interleukin-6. Science 264: 95-98, 1994. 
16. Akira S, Nishio Y, Inoue M, Wang XJ, Wei S, Matsusaka T, Yoshida K, Sudo T, Naruto M and Kishimoto T: Molecular cloning of APRF, a novel IFN-stimulated gene factor 3 p91-related transcription factor involved in the gp130-mediated signaling pathway. Cell 77: 63-71, 1994.

17. Garcia R, Yu CL, Hudnall A, Catlett R, Nelson KL, Smithgall T, Fujita DJ, Ethier SP and Jove R: Constitutive activation of Stat 3 in fibroblasts transformed by diverse oncoproteins and in breast carcinoma cells. Cell Growth Differ 8: 1267-1276, 1997.

18. Lutticken C, Wegenka UM, Yuan J, et al: Association of transcription factor APRF and protein kinase Jak1 with the interleukin-6 signal transducer gp130. Science 263: 89-92, 1994.

19. Migone TS, Lin JX, Cereseto A, Mulloy JC, O'Shea JJ, Franchini $\mathrm{G}$ and Leonard WJ: Constitutively activated Jak-STAT pathway in T cells transformed with HTLV-I. Science 269: 79-81, 1995.

20. Darnell JE Jr: STATs and gene regulation. Science 277: $1630-1635,1997$

21. Bromberg $\mathbf{J}$ and Wang TC: Inflammation and cancer: IL-6 and STAT3 complete the link. Cancer Cell 15: 79-80, 2009.

22. Zushi S, Shinomura Y, Kiyohara T, Miyazaki Y, Kondo S, Sugimachi M, Higashimoto Y, Kanayama S and Matsuzawa Y: STAT3 mediates the survival signal in oncogenic rastransfected intestinal epithelial cells. Int J Cancer 78: 326-330, 1998
23. Masuda M, Suzui M, Yasumatu R, Nakashima T, Kuratomi Y, Azuma K, Tomita K, Komiyama $\mathrm{S}$ and Weinstein IB: Constitutive activation of signal transducers and activators of transcription 3 correlates with cyclin D1 overexpression and may provide a novel prognostic marker in head and neck squamous cell carcinoma. Cancer Res 62: 3351-3355, 2002.

24. Newman DJ, Cragg GM and Snader KM: The influence of natural products upon drug discovery. Nat Prod Rep 17: 215-234, 2000.

25. Gordaliza M: Natural products as leads to anticancer drugs. Clinical and Translational Oncology 9: 767-776, 2007.

26. Ju HK, Baek SH, An RB, Bae K, Son KH, Kim HP, Kang SS, Lee SH, Son JK and Chang HW: Inhibitory effects of nardostachin on nitric oxide, prostaglandin E2, and tumor necrosis factor-alpha production in lipopolysaccharide activated macrophages? Biol Pharm Bull 26: 1375-1378, 2003.

27. Chiu LC, Ho TS, Wong EY and Ooi VE: Ethyl acetate extract of Patrinia scabiosaefolia downregulates anti-apoptotic Bcl-2/ Bcl-XL expression, and induces apoptosis in human breast carcinoma MCF-7 cells independent of caspase-9 activation. J Ethnopharmacol 105: 263-268, 2006.

28. Adams JM and Cory S: The Bcl-2 apoptotic switch in cancer development and therapy. Oncogene 26: 1324-1337, 2007.

29. Longley DB, Allen WL and Johnston PG: Drug resistance, predictive markers and pharmacogenomics in colorectal cancer. Biochim Biophys Acta 1766: 184-196, 2006.

30. Boose G and Stopper H: Genotoxicity of several clinically used topoisomerase II inhibitors. Toxicol Lett 116: 7-16, 2000. 